\title{
Carcass characteristics of lambs fed spineless cactus as a replacement for sugarcane
}

\author{
Juliana Paula Felipe de Oliveira, ${ }^{1, *}$, Marcelo de Andrade Ferreira', Adryanne Marjorie Souza Vitor Alves ${ }^{1}$, \\ Ana Caroline Cerqueira de Melo ${ }^{1}$, Ida Barbosa de Andrade', Stela Antas Urbano², \\ Juraci Marcos Alves Suassuna ${ }^{3}$, Leonardo José Assis de Barros ${ }^{1}$, and Tobias Tobit de Barros Melo ${ }^{1}$
}

\author{
* Corresponding Author: \\ Juliana Paula Felipe de Oliveira \\ Tel: +55-81-33206569, Fax: +55-81-33206555, \\ E-mail: jupaula.oliv@yahoo.com.br
}

${ }^{1}$ Department of Animal Science, Federal Rural University of Pernambuco, Recife 52171900, Brazil

2 Department of Animal Science, Federal University of Rio Grande do Norte, Macaíba 59280000, Brazil

${ }^{3}$ Department of Animal Science, Federal University of

Paraíba, Areia 58397000, Brazil

\section{ORCID}

Juliana Paula Felipe de Oliveira https://orcid.org/0000-0001-9005-5272

Marcelo de Andrade Ferreira

https://orcid.org/0000-0002-9155-4388 Adryanne Marjorie Souza Vitor Alves

https://orcid.org/0000-0001-8887-4279

Ana Caroline Cerqueira de Melo

https://orcid.org/0000-0002-4593-5585

Ida Barbosa de Andrade

https://orcid.org/0000-0001-5879-5318

Stela Antas Urbano

https://orcid.org/0000-0002-0033-3601

Juraci Marcos Alves Suassuna

https://orcid.org/0000-0003-4974-6092

Leonardo José Assis de Barros

https://orcid.org/0000-0002-0339-4696

Tobias Tobit de Barros Melo

https://orcid.org/0000-0002-4872-2577

Submitted May 13, 2017; Revised Jul 7, 2017; Accepted Aug 8, 2017
Objective: Fresh sugarcane has been a new roughage source for ruminant's in semiarid regions, a function of the decline of sugar and alcohol industry in recent years. However, there is little data published regarding lambs fed sugarcane associated with spineless cactus. This study evaluated the effect of sugarcane replacement with spineless cactus $(0 \%, 33 \%, 66 \%$, and $100 \%$ ) in the diet of Santa Inês lambs on carcass characteristics.

Methods: Thirty-six non-castrated Santa Ines lambs at four months of age and an initial body weight of $22 \pm 2.3 \mathrm{~kg}$ were assigned in a randomized block design and slaughtered after 70 days of confinement. The effects of spineless cactus as a replacement for sugarcane in the diet of the lambs on the carcass characteristics, commercial cut weight and yield, leg tissue composition, and carcass measurements were studied.

Results: The study revealed quadratic behavior in slaughter body weight, and hot and cold carcass weight, with maximum values of $38.60,18.60$, and $18.11 \mathrm{~kg}$ and replacement levels of $40.18 \%, 44.42 \%$, and $43.14 \%$, respectively. The cold carcass yield presented an increasing linear behavior. The compactness index of carcass and leg presented a quadratic effect, with estimated maximal values of 0.28 and $0.57 \mathrm{~kg} / \mathrm{cm}$ and replacement levels of $43.37 \%$ and $45.5 \%$, respectively. The weights of commercial cuts of leg, loin, shoulder, and breast showed quadratic behavior, with maximum values of $2.79,0.852,1.46$, and $1.30 \mathrm{~kg}$ and replacement levels of $49.5,45.32,39.0$, and 40.7 , respectively. For tissue composition, quadratic behavior was verified for leg weight, subcutaneous fat, and total fat.

Conclusion: The replacement of sugarcane by spineless cactus at level $44 \%$ is recommended for finishing lambs considering that this level improved most of the carcass characteristics, weights, and yields of commercial cuts and leg tissue composition.

Keywords: Carcass Characteristics; Roughage; Spineless Cactus

\section{INTRODUCTION}

Whether due to socioeconomics, culture, or even the adaptability of small ruminants, the northeastern semi-arid region naturally has a vocation to the development of meat sheep production. However, the significant importation of sheep meat from Uruguay, Chile, and Argentina indicates that there are still problems that interfere with the productive efficiency of the region. Although there are other points to be worked on in the establishment of the productive chain, nutritional problems due to seasonality in the roughage supply are mainly responsible for the insufficient and irregular supply of sheep meat to the market [1,2].

Increasing the herd turnover rate requires intensification and shortening of the production cycle, which can be achieved in the short and medium term through the implementation of production systems in confinement. However, the low availability of food resources during 
the dry season and the high prices applied when reselling the few available ingredients in these periods [3] compromise the economic viability of production systems. Thus, the search for regionally adapted, less costly, and more accessible ingredients is seen as a strategy to produce carcasses with a differentiated quality pattern that will be obtained through the slaughter of young animals.

In this context, spineless cactus emerges as a potential solution due to its adaptation to semi-arid regions, its high dry matter (DM) production per unit area (40 ton DM/ha/yr), and, especially, its high energy content (58.68\% of non-fibrous carbohydrates) $[4,5]$. However, its use by ruminants is limited by its low content of neutral detergent fiber (NDF), making it necessary to associate it with a source of fiber with high effectiveness [6]. This source could be sugarcane, which, as a result of the sugarcane industry crisis in recent years, has been used on a large scale by farmers in the semi-arid region of the Brazilian Northeast due to its greater availability and lower cost when compared to other roughages.

Considering that reports dealing with fresh sugarcane use in sheep feeding are scarce, there is a need for studies that evaluate the influence of the diet on confined lamb carcass quality and the impacts on sheep meat $[7,8]$, aiming at finding alternative feeding systems adaptable to arid and semi-arid regions' growing conditions.

It was hypothesized that there may be a sugarcane/spineless cactus ratio that could maximize carcass characteristics and leg tissue composition. Therefore, the aim of this study was to evaluate the effect of replacing sugarcane by spineless cactus (Nopallea cochenillifera Salm Dyck) in lamb feeding on the leg tissue composition, carcass characteristics, commercial cut weight and yield.

\section{MATERIALS AND METHODS}

\section{Animal care}

All procedures were conducted in accordance with the guidelines set out by the Ethics Committee on Use of Animals for Research (CEUA) of the UFRPE under license number 009/ 2015.

\section{Animals, experimental design and experimental diets} The experiment was conducted at the Animal Science Department of the Federal Rural University of Pernambuco (UFRPE), Recife, Brazil. Thirty-six non-castrated, four-monthold, male Santa Inês lambs with an average initial body weight of $22 \pm 2.3 \mathrm{~kg}$ were used in a feedlot. The experimental design included randomized blocks with four treatments and nine replicates, and the animals' initial weight was the criterion for block formation. Prior to the trial, the lambs were weighed, identified, and distributed in individual pens $(1.2 \times 1.6 \mathrm{~m})$ with a feeder and drinker. In addition, the lambs were vaccinated against clostridial diseases and received treatments against endoparasites and ectoparasites, as well as vitamin supplements containing vitamin $\mathrm{A}, \mathrm{D}$, and $\mathrm{E}$.

The experimental diets consisted of four levels $(0 \%, 33 \%$, $66 \%$, and $100 \%$ on DM basis) of spineless cactus in replacement of sugarcane. The roughage:concentrate ratio was $48: 52$ on a DM basis with sugarcane (Saccharum officinarum L.) and spineless cactus cv. Miúda (Nopallea cochenillifera Salm Dyck) as roughage (Tables 1,2). The diet without spineless cactus was formulated to be isonitrogenous and to meet the nutritional requirements of lambs with $25 \mathrm{~kg}$ of body weight and an average daily gain of $200 \mathrm{~g}$, according to the National Research Council [9].

The spineless cactus used in the experiment was from the Agronomic Institute of Pernambuco Experimental Station located in the city of São Bento do Una (harvested every 7 days with a maturity of 2 years) and sugar cane (harvested daily with a maturity of 1 year) from the Sugarcane Experimental Station from Carpina, Federal Rural University of Pernambuco, located in the municipality of Carpina. The spineless cactus and the sugarcane were processed in specific fodder processor before the supply to the animals.

\section{Experimental procedures and sampling}

The experiment lasted for 100 days, of which 30 days were for adaptation to the diets and installations, and 70 days were for data and sample collection. The animals were fed twice daily (at 08:00 and 15:00). The amount of feed supplied was corrected daily to generate $5 \%$ to $10 \%$ of orts. Feeds and orts

Table 1. Chemical composition of ingredients used in the experimental diets ( $\mathrm{g} / \mathrm{kg}$ of DM)

\begin{tabular}{|c|c|c|c|c|c|}
\hline Item & Sugarcane & Spineless cactus & Ground corn & Soybean meal & Wheat bran \\
\hline Dry matter & 311 & 109 & 882 & 887 & 886 \\
\hline Organic matter & 979 & 844 & 986 & 929 & 947 \\
\hline Crude protein & 14.6 & 44.6 & 81.0 & 477 & 160 \\
\hline Ether extract & 10.2 & 14.7 & 38.7 & 13.7 & 32.4 \\
\hline aNDF(n) & 488 & 243 & 119 & 134 & 363 \\
\hline Non-fiber carbohydrates & 450 & 534 & 576 & 296 & 383 \\
\hline Acid detergent fiber & 335 & 146 & 280 & 94.7 & 131 \\
\hline Lignin & 58.6 & 25.1 & 6.6 & 16.2 & 38.0 \\
\hline
\end{tabular}

DM, dry matter; aNDF(n), neutral detergent fiber assayed with a heat stable amylase and corrected for ash and nitrogenous compounds. 
Table 2. Proportion of ingredients and chemical composition of the experimental diets

\begin{tabular}{lcccc}
\hline \multirow{2}{*}{ Ingredients (g/kg) } & \multicolumn{4}{c}{ Replacement levels (\%) } \\
\cline { 2 - 5 } & $\mathbf{0}$ & $\mathbf{3 3}$ & $\mathbf{6 6}$ & $\mathbf{1 0 0}$ \\
\hline Sugarcane & 477 & 318 & 159 & 0 \\
Spineless cactus & 0 & 159 & 318 & 477 \\
Ground corn & 190 & 200 & 211 & 221 \\
Soybean meal & 187 & 177 & 166 & 156 \\
Wheat bran & 121 & 121 & 121 & 121 \\
Urea/AS ${ }^{1)}$ & 10 & 10 & 10 & 10 \\
Salt & 5 & 5 & 5 & 5 \\
Mineral ${ }^{2)}$ & 10 & 10 & 10 & 10 \\
CP \% & 15.7 & 15.8 & 15.9 & 15.9 \\
Diet composition (g/kg of DM) & & & & \\
Dry matter & 473 & 326 & 249 & 201 \\
Organic matter & 942 & 921 & 901 & 880 \\
Matéria mineral & 56.6 & 77.6 & 98.6 & 119 \\
Crude protein & 157 & 157 & 158 & 159 \\
Ether extract & 18.7 & 19.7 & 20.7 & 21.6 \\
aNDF(n) & 324 & 285 & 246 & 207 \\
Non-fiber carbohydrates & 425 & 441 & 458 & 474 \\
Acid detergent fiber & 246 & 218 & 190 & 162 \\
Lignin & 48.1 & 43.3 & 38.5 & 33.7 \\
\hline CP & & &
\end{tabular}

$\mathrm{CP}$, crude protein; DM, dry matter; aNDF(n), neutral detergent fiber assayed with a heat stable amylase and corrected for ash and nitrogenous compounds.

1) 9 parts of urea and 1 part of ammonium sulphate (AS).

2) Nutrients/kg of product: Vit. A, 135.000 Ul; Vit. D $D_{31} 11,868.000$ Ul; Vit. E, 450 mg; Ca, 240 g; P, 71 g; K, 28.2 g; S, 20 g; Mg, 20 g; Co, 30 mg; Cu, 400 mg; Cr, 10 mg; Fe, 2,500 mg; I, 40 mg; Mn, 1,350 mg; Se, 15 mg; Zn, 1,700 mg; F (max.), $710 \mathrm{mg}$.

were weighed daily throughout the experimental period to calculate the voluntary intake.

After 70 days, the animals were solid fasted 12-hour preslaughter with only water access. Then, immediately before slaughter, they were weighed to obtain their slaughter body weight (SBW). At the time of slaughter, the animals were stunned by trauma to the head and were then bled at the carotid artery and the jugular vein.

The gastrointestinal tract content (GTC) was quantified by the difference between weights of the full and empty gastrointestinal tract. After skinning and evisceration, the head and the feet were removed from each animal and the hot carcass weight $(\mathrm{HCW})$ was registered. Also, carcass $\mathrm{pH}$ readings were taken at 0 and 24 hours post mortem from the Semimembranosus muscle with the aid of a $\mathrm{pH}$ meter/insertion thermometer.

The carcasses were chilled for 24 hours in a $4^{\circ} \mathrm{C}$ cold room and hung on hooks, with the metatarsal joints spaced at $17 \mathrm{~cm}$. After cooling, the carcasses were weighed, deducting the weight of the kidney and perirenal fat, to obtain the cold carcass weight (CCW) and to calculate the chilling losses (CL [\%] = HCW$\mathrm{CCW} / \mathrm{HCW} \times 100)$. The commercial yield was calculated as $\mathrm{CY}(\%)=\mathrm{CCW} / \mathrm{SBW} \times 100$. After the cooling period, the following measures were taken on the whole carcass: internal length, leg length, and rump width. Subsequently, the leg compactness index (LCI), the ratio between rump width and leg length, the carcass compactness index (CCI), and the ratio between the CCW and the carcass inner length were calculated [10].

After the measurements, the carcasses were cut in half, and half of each carcass was weighed. The left half was sectioned into six anatomic regions [10], originating the following cuts: neck, shoulder, leg, loin, ribs, and breast. We recorded the individual weights of each cut and then calculated the yield of each cut coming from the left half of the carcass compared to its reconstituted weight.

In the left half of the carcass, a cross-section between the 12th and 13th ribs was made to measure the longissimus muscle area (LMA) of the longissimus dorsi muscle by tracing the muscle's contour on a transparent plastic sheet for later area determination using the average of three readings from a digital planimeter (Haff, Digiplan model, Pfronten, Baviera, Germany). Additionally, a caliper was used to measure the thickness of the subcutaneous fat on the longissimus dorsi muscle section (between the last thoracic vertebra and the first lumbar) at two-thirds the total length of the LMA [10].

The left fillet of each animal was vacuum-packed in a highdensity polyethylene bag and frozen at $-10^{\circ}$ to evaluate its tissue composition. The composition was determined using the methodology described by [11], in which the 36 left fillets, which had previously been stored and were then gradually thawed while being kept at a temperature of approximately $4^{\circ} \mathrm{C}$ for 24 hours, were dissected. During the dissections, the five main muscles associated with the femur (biceps femures, semimembranosus, semitendinosus, quadriceps femoris, and adductor) were removed intact and then weighed to calculate the leg muscularity index according to the following formula: LMI $=\sqrt{(\mathrm{W} 5 \mathrm{M} / \mathrm{FL})} / \mathrm{FL}$, where W5M represents the weight of the five muscles (g) and FL is femur length (cm) [12].

\section{Statistical analysis}

The experimental design was complete randomized blocks and the animals' initial weight was the criterion for block formation. The variables studied were analyzed with the PROC MIXED option in SAS software (version 9.1), adopting 0.05 as the critical level of probability for type I error considering fixed effect, the treatment and random effects, the block and treatment $\times$ block variables according to the following model:

$$
\mathrm{Y}_{i j k}=\mu+\tau_{i}+\beta_{j}+\tau \beta_{i j}+\varepsilon_{i j k}
$$

Where, $Y_{i j k}$ is the experimental response measured on the treatment $i$, block $j$, and repetition $k ; \mu$ is the general mean; $\tau_{i}$ is the treatment effect $i$, where $i=1,2,3$, and $4 ; \beta j$ is the block effect $j ; \tau \beta_{i j}=$ the interaction effect of treatment $i$ and block $j$; and $\varepsilon_{i j k}$ is the random error with mean 0 and variance $\sigma^{2}$ ). 


\section{RESULTS AND DISCUSSION}

\section{Nutrient intake and carcass characteristics}

The intakes of DM, crude protein, and digestible organic matter presented quadratic behavior with estimated maximum values of $1.320,0.219$, and $0.845 \mathrm{~kg} / \mathrm{d}$ with $45 \%, 38.80 \%$, and $44.93 \%$ of replacement of sugarcane by spineless cactus, respectively (Table 3). As a consequence and following the nutrient intake, the SBW, HCW, and CCW showed quadratic behavior, with estimated maximum values of $38.60,18.70$, and 18.11 $\mathrm{kg}$ for $40.18 \%, 44.42 \%$, and $43.14 \%$ of replacement (Table 3 ), respectively.

The digestible organic matter quadratic behavior $(44.93 \%$ of replacement) reflected the similar behavior of the parameters that determine tissue deposition in the carcass, verifying maximum values for SBW, HCW, and CCW when spineless cactus replaced sugarcane in $40.18 \%, 44.42 \%$, and $43.14 \%$, respectively. These results evidenced the influence of energy intake on tissue deposition in sheep, with consequent gains in carcasses $[13,14]$. The maximum values for HCW and CCW found in this study ( 18.70 and $18.11 \mathrm{~kg}$, respectively) meet the minimum values for carcass characterization with good quality, with HCWs equal to or greater than those obtained in studies using conventional diets with corn, soybean, and Tifton grass hay in their composition $[15,16]$.

The CY increased linearly as a function of the increase of spineless cactus in the diets (Table 3). It can be inferred that this happened due to the linear decrease observed for the GTC according to sugarcane replacement by spineless cactus, and because they are inversely proportional, the linear increase of the yield was verified. The result observed for GTC is a direct consequence of fiber intake, since sugarcane, an ingredient with low ruminal degradation fiber, low digestibility, and high retention in the tract was replaced by spineless cactus, which has low NDF content, high non-fiber carbohydrates content, and high ruminal degradation. It is likely that the replacement caused an increased passage rate in the gastrointestinal tract, since the consumption of diets with high fiber content is controlled by physical factors such as passage rate and ruminal filling $[17,18]$.

Uniformity was observed for subcutaneous fat thickness (SFT), whose mean value was $0.84 \mathrm{~mm}$. Although below the 1 to $2 \mathrm{~mm}$ range established by [19] for the "low fat" category, subcutaneous fat was sufficient to ensure adequate values of CL \%, which were not influenced by the replacement and showed an average of $3 \%$, remaining within the range of $2 \%$ to $4 \%$ recommended by [20].

It is possible that low-fat deposition is related to the intrinsic factor of the Santa Inês breed, which presents low deposition of subcutaneous fat but accumulates large amounts of internal fat [21], as observed in Table 4, where internal fat deposits followed the quadratic behavior of energy intake. Moreover, it is worth mentioning that the subcutaneous fat is deposited late when compared to other fatty deposits [22], which may

Table 3. Nutrient intake and carcass characteristics of lambs fed diets containing different replacement levels of sugarcane by spineless cactus

\begin{tabular}{|c|c|c|c|c|c|c|c|}
\hline \multirow{2}{*}{ Item } & \multicolumn{4}{|c|}{ Replacement levels (\%) } & \multirow{2}{*}{ SEM } & \multicolumn{2}{|c|}{$p$ value } \\
\hline & 0 & 33 & 66 & 100 & & $\mathrm{~L}$ & Q \\
\hline \multicolumn{8}{|l|}{ Daily intake $(\mathrm{kg} / \mathrm{d})$} \\
\hline Dry matter ${ }^{1)}$ & 1.10 & 1.350 & 1.198 & 0.974 & 0.056 & 0.009 & $<0.0001$ \\
\hline Crude protein $^{2)}$ & 0.189 & 0.235 & 0.191 & 0.162 & 0.009 & 0.002 & 0.0001 \\
\hline $\mathrm{DOM}^{3)}$ & 0.716 & 0.832 & 0.820 & 0.648 & 0.039 & 0.166 & 0.0003 \\
\hline \multicolumn{8}{|c|}{ Carcass characteristcs } \\
\hline GTC $(k g)$ & 6.43 & 5.68 & 5.30 & 3.84 & 0.346 & $<0.0001$ & 0.234 \\
\hline $\mathrm{SBW}(\mathrm{kg})^{4)}$ & 35.77 & 39.24 & 36.65 & 32.78 & 1.642 & 0.027 & 0.002 \\
\hline $\mathrm{HCW}(\mathrm{kg})^{5)}$ & 17.17 & 19.06 & 17.90 & 16.62 & 0.898 & 0.333 & 0.019 \\
\hline $\operatorname{CCW}(\mathrm{kg})^{6)}$ & 16.67 & 18.48 & 17.38 & 16.10 & 0.872 & 0.320 & 0.019 \\
\hline CY $(\%)$ & 46.53 & 47.00 & 47.41 & 49.15 & 0.589 & 0.002 & 0.264 \\
\hline$C L(\%)$ & 2.89 & 3.12 & 2.87 & 3.13 & 0.191 & 0.578 & 0.952 \\
\hline SFT (mm) & 0.88 & 0.87 & 0.78 & 0.83 & 0.063 & 0.417 & 0.639 \\
\hline $\operatorname{LMA}\left(\mathrm{cm}^{2}\right)$ & 12.68 & 13.54 & 13.21 & 12.20 & 0.602 & 0.478 & 0.102 \\
\hline $\mathrm{CCl}(\mathrm{kg} / \mathrm{cm})^{7)}$ & 0.26 & 0.29 & 0.27 & 0.25 & 0.011 & 0.189 & 0.004 \\
\hline $\mathrm{LCl}(\mathrm{cm} / \mathrm{cm})^{8)}$ & 0.55 & 0.58 & 0.57 & 0.54 & 0.012 & 0.828 & 0.035 \\
\hline pH 0 hours & 6.81 & 6.89 & 6.97 & 6.93 & 0.064 & 0.116 & 0.338 \\
\hline pH 24 hours & 5.60 & 5.57 & 5.61 & 5.56 & 0.017 & 0.259 & 0.496 \\
\hline
\end{tabular}

SEM, standard error of the mean; L, linear effect; Q, quadratic effect; DOM, digestible organic matter; GTC, gastrointestinal tract content; SBW, slaughter body weight; HCW, hot carcass weight; CCW, cold carcass weight; CY, commercial yield; CL, chilling losses; SFT, subcutaneous fat thickness; LMA, Longissimus muscle área; CCI, carcass compactness índex; $\mathrm{LCl}$, leg compactness índex.

1) $Y=1.117+0.009 x-0.0001 x^{2} .{ }^{2)} Y=194.42+1.2883 x-0.0166 x^{2} .{ }^{3)} Y=714,74+5.7972 x-0.0645 x^{2} .{ }^{4)} Y=36.022+0.1286 x-0,0016 x^{2}$

${ }^{5)} Y=17.322+0.0622 x-0.0007 x^{2} .{ }^{6} Y=16.812+0.0604 x-0.0007 x^{2} .{ }^{77} Y=262.6+0.963 x-0.0111 x^{2} .{ }^{8)} Y=551.09+1.2207-0.0134 x^{2}$. 
Table 4. Internal fat of the gastrointestinal tract of lambs fed diets containing different replacement levels of sugarcane by spineless cactus

\begin{tabular}{|c|c|c|c|c|c|c|c|}
\hline \multirow{2}{*}{ Items (kg) } & \multicolumn{4}{|c|}{ Replacement levels (\%) } & \multirow{2}{*}{ SEM } & \multicolumn{2}{|c|}{$p$ value } \\
\hline & 0 & 33 & 66 & 100 & & $\mathbf{L}$ & Q \\
\hline Mesentery fat ${ }^{1)}$ & 0.319 & 0.404 & 0.340 & 0.290 & 0.033 & 0.141 & 0.006 \\
\hline Omentum fat ${ }^{2)}$ & 0.549 & 0.749 & 0.653 & 0.455 & 0.065 & 0.104 & 0.0001 \\
\hline Renal-pelvic fat ${ }^{3)}$ & 0.329 & 0.462 & 0.380 & 0.296 & 0.047 & 0.236 & 0.003 \\
\hline Total internal fat ${ }^{4)}$ & 1.279 & 1.719 & 1.496 & 1.136 & 0.138 & 0.147 & 0.0001 \\
\hline
\end{tabular}

SEM, standard error of the mean; L, linear effect; $Q$, quadratic effect

${ }^{1)} Y=327.43+2.5485 x-0.03 x^{2} .{ }^{2)} Y=559.33+7.7456 x-0.0889 x^{2} .{ }^{3)} Y=340.06+4.2905 x-0.0484 x^{2} .{ }^{4)} Y=1.3066+0.0159 x-0.0002 x^{2}$

also have contributed to the low SFT values.

The LMA was not influenced by the replacement, presenting an average of $12.90 \mathrm{~cm}^{2}$, similar to the values reported by [14], who found average values of $12.56 \mathrm{~cm}^{2}$ of LMA in Santa Inês sheep carcass, and [23], who obtained an average value of $11.20 \mathrm{~cm}^{2}$ for Santa Inês sheep fed Tifton grass hay and fresh spineless cactus. The average value verified for the LMA in this study is compatible with high muscular carcasses.

The CCI and LCI, variables highly correlated with carcass and leg muscularity degree, respectively, also follow the quadratic behavior of energy intake. The CCI showed the maximum value of tissue storage estimated at $0.28 \mathrm{~kg} / \mathrm{cm}$ with $43.37 \%$ replacement, whereas the highest LCI $(0.57)$ was verified when spineless cactus replaced sugarcane by $45.5 \%$ (Table 3 ).

The replacement of sugarcane by spineless cactus did not affect the carcass $\mathrm{pH}$ values at 0 and 24 hours post mortem, and they were within the normal range of 5.5 to 5.8 for sheep meat after slaughter [24], indicating that the pre-slaughter management techniques were applied efficiently, avoiding the occurrence of animal stress. Normal $\mathrm{pH}$ values suggest that other indicators of quality parameters, such as softness and color, tend to have good results, since they are directly linked to $\mathrm{pH}$.

\section{Weights and yields of commercial cuts}

The weights of the leg, loin, shoulder, and breast commercial cuts followed the energy intake, showing quadratic behavior with maximum values estimated at $2.79,0.85,1.46$, and 1.30 $\mathrm{kg}$ with $49.5 \%, 45.3 \%, 39.0 \%$, and $40.7 \%$ replacement of sugarcane by spineless cactus, respectively (Table 5). These cuts are those that accumulate a greater amount of muscular mass and, therefore, undergo stronger nutritional influence. Table 6 shows a higher proportion of muscles in the leg $(67.82 \%$ on average). Higher proportions of muscle mass were also observed [25] in lambs slaughtered at $32 \mathrm{~kg}$, with $67.89 \%$ for leg, $55.25 \%$ for shoulder, and $65.32 \%$ for loin. For this reason, the shoulder, leg, and loin are the most important cuts of the carcass because they are the noblest and of greatest commercial value [26].

Commercial cut yields were not influenced by replacement. The main commercial cuts of the carcass (leg, loin, and shoulder) in meat sheep breeds must show the sum of their yields close to $60 \%$ [27]. The average obtained in the sum of these cuts in the present study was $58.29 \%$, demonstrating that the

Table 5. Commercial cut weight and yield of lambs fed diets containing different replacement levels of sugarcane by spineless cactus

\begin{tabular}{|c|c|c|c|c|c|c|c|}
\hline \multirow{2}{*}{ Items } & \multicolumn{4}{|c|}{ Replacement levels (\%) } & \multirow{2}{*}{ SEM } & \multicolumn{2}{|c|}{$p$ value } \\
\hline & 0 & 33 & 66 & 100 & & $\mathbf{L}$ & Q \\
\hline \multicolumn{8}{|c|}{ Commercial cuts (kg) } \\
\hline $\operatorname{Leg}^{11}$ & 2.54 & 2.79 & 2.64 & 2.35 & 0.166 & 0.202 & 0.044 \\
\hline $\operatorname{Loin}^{2)}$ & 0.76 & 0.86 & 0.82 & 0.73 & 0.044 & 0.446 & 0.013 \\
\hline Shoulder ${ }^{3)}$ & 1.38 & 1.49 & 1.40 & 1.28 & 0.065 & 0.134 & 0.055 \\
\hline Breast $^{4)}$ & 1.17 & 1.35 & 1.22 & 1.10 & 0.077 & 0.105 & 0.005 \\
\hline Ribs & 1.24 & 1.32 & 1.25 & 1.17 & 0.072 & 0.350 & 0.170 \\
\hline Neck & 0.92 & 0.96 & 0.98 & 0.91 & 0.066 & 0.992 & 0.373 \\
\hline \multicolumn{8}{|c|}{ Commercial cut yield (\%) } \\
\hline Leg & 31.68 & 31.62 & 31.63 & 30.54 & 0.934 & 0.423 & 0.584 \\
\hline Loin & 9.54 & 9.89 & 9.97 & 9.75 & 0.349 & 0.660 & 0.416 \\
\hline Shoulder & 17.37 & 17.04 & 16.91 & 17.30 & 0.602 & 0.895 & 0.512 \\
\hline Breast & 14.56 & 15.31 & 14.50 & 14.49 & 0.476 & 0.609 & 0.388 \\
\hline Ribs & 15.42 & 15.12 & 15.15 & 15.73 & 0.436 & 0.617 & 0.315 \\
\hline Neck & 11.42 & 10.99 & 11.81 & 12.17 & 0.414 & 0.108 & 0.348 \\
\hline
\end{tabular}

SEM, standard error of the mean; $L$, linear effect; $Q$, quadratic effect.

1) $Y=2.553+0.0099 x-0.0001 x^{2} .{ }^{2)} Y=764.79+3.8528 x-0.0425 x^{2} .{ }^{3)} Y=1.3889+0.0039 x-0.00005 x^{2} .{ }^{4)} Y=1.8866+0.0057 x-0.00007 x^{2}$ 
Table 6. Leg tissue composition of lambs fed diets containing different replacement levels of sugarcane by spineless cactus

\begin{tabular}{|c|c|c|c|c|c|c|c|}
\hline \multirow{2}{*}{ Component } & \multicolumn{4}{|c|}{ Replacement levels (\%) } & \multirow{2}{*}{ SEM } & \multicolumn{2}{|c|}{$p$ value } \\
\hline & 0 & 33 & 66 & 100 & & $\mathrm{~L}$ & Q \\
\hline $\operatorname{Leg}(g)^{1)}$ & $2,525.9$ & $2,772.4$ & $2,652.4$ & $2,401.3$ & 140.60 & 0.329 & 0.034 \\
\hline Muscles $(g)^{2)}$ & $1,652.7$ & $1,804.4$ & $1,788.7$ & $1,557.7$ & 82.59 & 0.359 & 0.013 \\
\hline Bones $(g)$ & 494.1 & 549.3 & 497.5 & 517.2 & 32.87 & 0.900 & 0.578 \\
\hline Subcutaneous fat $(\mathrm{g})^{3)}$ & 110.1 & 164.7 & 152.5 & 125.8 & 12.14 & 0.487 & 0.001 \\
\hline Intermuscular fat (g) & 89.0 & 108.2 & 93.8 & 88.5 & 9.23 & 0.641 & 0.118 \\
\hline Total fat $(g)^{4)}$ & 199.7 & 273.4 & 246.8 & 215.01 & 17.65 & 0.764 & 0.001 \\
\hline Other tissues (g) & 54.1 & 65.93 & 60.81 & 60.81 & 8.50 & 0.701 & 0.495 \\
\hline Muscles (\%) & 69.67 & 66.92 & 68.48 & 66.23 & 0.990 & 0.060 & 0.803 \\
\hline Bones (\%) & 20.03 & 20.56 & 19.53 & 22.17 & 0.876 & 0.169 & 0.226 \\
\hline Total fat $(\%)^{5)}$ & 8.09 & 10.11 & 9.64 & 8.97 & 0.511 & 0.337 & 0.012 \\
\hline Other tissues (\%) & 2.21 & 2.41 & 2.36 & 2.58 & 0.271 & 0.383 & 0.963 \\
\hline Muscle:boné & 3.49 & 3.26 & 3.81 & 3.01 & 0.319 & 0.541 & 0.382 \\
\hline Muscle:fat ${ }^{6)}$ & 8.78 & 6.64 & 7.38 & 7.65 & 0.505 & 0.266 & 0.028 \\
\hline $\mathrm{LMI}^{7)}$ & 0.36 & 0.38 & 0.39 & 0.37 & 0.008 & 0.449 & 0.019 \\
\hline
\end{tabular}

SEM, standard error of the mean; L, linear effect; Q, quadratic effect; LMI, leg muscularity index.

1) $Y=2537.6+9.634 x-01112 x^{2} .{ }^{2)} Y=1650.1+7.6676 x-0.0858 x^{2},{ }^{3)} Y=112.84+1.9253 x-0.0182 x^{2}$

4) $Y=204.63+2.416 x-0.0236 x^{2} .{ }^{5)} Y=8.2087+0.0668 x-0.0006 x^{2}{ }^{26} Y=8.6079-0,0619 x+0.0005 x^{2}$

7) $Y=35.903+0.1022 x-0.0009 x^{2}$

replacement did not compromise the quality of the noblest cuts.

\section{Leg tissue composition}

Among the leg tissue components evaluated (Table 6), the muscles presented the highest weight $(1,618.80 \mathrm{~g})$, followed by bones $(391.09 \mathrm{~g})$ and fat ( $326.09 \mathrm{~g})$. These tissue components present different developmental orders, where, according to [28], the bone tissue presents earlier growth, followed by muscle and, finally, adipose tissue. Analyzing these values, especially the muscular weight, it is possible to verify the aptitude of Santa Inês sheep for meat production, especially considering the average percentage of muscular deposition of $67.82 \%$.

For tissue composition, a quadratic effect was verified for the weight of the leg, muscles, subcutaneous fat, and total fat, with maximum values estimated at 2,743.79, 1,821.9, 163.75, and 266.46 g with $43.29 \%, 44.70 \%, 52.89 \%$, and $51.18 \%$ of replacement, respectively, which was a probable consequence on the quadratic effect observed for nutrient intake, especially energy.

The leg muscularity index, which is one of the main indicators of the number of muscles in this section, showed quadratic behavior, with a maximum value estimated at $0.38 \%$ with $56.77 \%$ of replacement, following the energy intake. In the present study, the deposition of adipose tissue in the leg followed the quadratic behavior of the digestible organic matter intake. Similar behavior was observed by [29], who evaluated cassava wastewater in replacement of corn and found that when energy intake decreased, fat deposition in the leg also decreased. The author attributed this to the high energy requirement for adipose tissue deposition.
The tissue components of bone and other tissues were not influenced by the replacement of sugarcane with spineless cactus. The muscle:fat ratio was influenced by replacement, presenting quadratic behavior with a maximum value of $6.69 \%$ with $61.9 \%$ of replacement. The muscle:bone ratio was not influenced by the replacement, probably because the weight of the bones did not change.

The muscle:bone ratio is an objective measure often associated with increased muscle mass deposition [12]. However, [30] stated that, from the point of view of meat quality, the muscle:fat ratio can be considered the most important, since the presence of fat has great importance in the acceptance of meat, as it influences the characteristics of texture, juiciness, and flavor.

The combination of spineless cactus and sugarcane proved to be extremely promising for use in confined sheep diets. The $44 \%$ replacement showed much higher results than in other studies. Studies by [15] and [16] with Santa Inês animals fed conventional feeds composed of Tifton grass hay, corn, and soybean and using the same roughage:concentrate ratio [15] showed a SBW of $30.7 \mathrm{~kg}$, HCW of $13.2 \mathrm{~kg}$, and CCW of 12.7 kg. For SBW, HCW, and CCW, [16] found 34.7, 15.9, and 15.3 $\mathrm{kg}$, respectively. Observing Table 3 and comparing with the above-mentioned values, it may be asserted that sugarcane and spineless cactus are unconventional ingredients that are suitable for sheep feed, considering that the values obtained for referred variables were higher than the verified results with these conventional diets, with SBW, HCW, and CCW values of $38.60,18.70$, and $18.11 \mathrm{~kg}$, respectively. 


\section{CONCLUSION}

The replacement of sugarcane by spineless cactus at level $44 \%$ is recommended for finishing lambs considering that this level improved most of the carcass characteristics, weights, and yields of commercial cuts and leg tissue composition.

\section{CONFLICT OF INTEREST}

We certify that there is no conflict of interest with any financial organization regarding the material discussed in the manuscript.

\section{ACKNOWLEDGMENTS}

The authors are grateful for the support and funding from the Pernambuco Foundation for Science and Technology (FACEPE).

\section{REFERENCES}

1. Silva NV, Costa RG, Freitas CRG, Galindo MCT, Silva LS. Sheep feeding in semi-arid regions of Brazil. Acta Vet Bras 2010;4:233-41.

2. Alves LGC, Osório JCS, Fernandes ARM, Ricardo HA, Cunha $\mathrm{CM}$. Meat production in sheep with focus on consumer. Encicl Biosf 2014;10:2399-415.

3. Tikam K, Phatsara C, Sorachakula C, et al. In vitro gas production, in vivo nutrient digestibilities, and metabolisable energy concentrations for sheep of fresh and conserved pangola grass. Small Rumin Res 2015;128:34-40.

4. Santos DC, Farias I, Lira MA, et al. Management and use of spineless cactus (Opuntia and Nopalea) in Pernambuco. Recife, Brazil: Agronomic Institute of Pernambuco; 2006. 48 p. (Documents, 30).

5. Ferreira MA, Bispo SV, Rocha Filho RR, et al. The use of cactus as forage for dairy cows in semi-arid regions of Brazil. In: Konvalina P, ediotr. Organic farming and food production. (Org.): South Bohemia, Czech Republic: InTech; 2012. pp. 1-22.

6. Monteiro CCF, Melo AAS, Ferreira MAF, et al. Replacement of wheat bran with spineless cactus (Opuntia ficus indica Mill $\mathrm{cv}$ Gigante) and urea in the diets of Holstein $\times$ Gyr heifers. Trop Anim Health Prod 2014;46:1149-54.

7. Gusha J, Halimani TE, Ngongoni NT, Ncube S. Effect of feeding cactus-legume silages on nitrogen retention, digestibility and microbial protein synthesis in goats. Anim Feed Sci Technol 2015;206:1-7.

8. Pereira L, Pires AJV, Carvalho GGP, et al. Nutritional characteristics of lambs meat fed diets with cotton cake. J Food Qual 2016;39:140-9.

9. National Research Council (NRC). Nutrient requirements of small ruminants: sheep, goats, cervids, and new world camelids. Washington, DC, USA: National Academy Press; 2007.

10. Cezar MF, Souza WH. Sheep and goat carcasses: obtaining, evaluation and classification. Uberaba, MG, Brazil: Tropical Agriculture Publishing; 2007. 147 p.

11. Brown AJ, Williams DR. Sheep carcass evaluation: measurement of composition using a standardized butchery method. Langford, England: Agricultural Research Council; Meat Research Council; 1979. 16 p.

12. Purchas RW, Davies AS, Abdullah AY. An objective measure of muscularity: changes with animal growth and differences between genetic lines of Southdown sheep. Meat Sci 1991;30: 81-94.

13. Piola Júnior W, Ribeiro ELA, Mizubuti IY, et al. Levels of energy in the feeding of feedlot lambs and the regional and tissue carcass composition. R Bras Zootec 2009;38:1797-802.

14. Pereira ES, Pimentel PG, Fontenele RM, et al. Characteristics and yields of carcass and cuts in Santa Ines sheep fed with different concentrations of metabolizable energy. Acta Sci Anim Sci 2010;32:431-7.

15. Santos Filho HB, Véras RML, Ferreira MA, et al. Liquid residue of cassava as a replacement for corn in the diets of sheep. Trop Anim Health Prod 2015;47:1083-8.

16. Alves FJL, Ferreira MA, Urbano SA, et al. Performance of lambs fed alternative protein sources to soybean meal. $\mathrm{R}$ Bras Zootec 2016;45:145-50.

17. Mariz LDS, Valadares Filho SC, Detmann E, et al. Intake and ruminal digestion determined using omasal and reticular digesta samples in cattle fed diets containing sugar cane in natura or ensiled sugar cane compared with maize silage. Livest Sci 2013;155:71-6.

18. Silva AEM, Lira AT, Ferreira MA, et al. Sugarcane bagasse as roughage in sheep diet. R Bras Saúde Prod Anim 2015;16:11829.

19. Silva Sobrinho AG. Sheep farming. Jaboticabal, Brazil: Funep; 2001. $302 \mathrm{p}$.

20. Sañudo C, Sierra I. Carcass quality in ovine species. Ovi 1986;1: 127-53.

21. Medeiros GR, Costa RG, Andrade MGLP, et al. Fat depots in carcass of Santa Ines and Morada Nova sheep slaughtered at different weights. Actas Iberoam Conserv Anim 2011;1:243-6.

22. Warriss PD. Meat science: an introductory text. Wallingford, UK: CABI Publishing; 2000. 310 p.

23. Andrade SFJ, Batista AMV, Carvalho FFR, et al. Fresh or dehydrated spineless cactus in diets for lambs. Acta Sci Anim Sci 2016;38:155-61.

24. Della Malva A, Albenzio M, Annicchiarico G, et al. Relationship between slaughtering age, nutritional and organoleptic properties of Altamurana lamb meat. Small Rumin Res 2016; 135:39-45.

25. Pinheiro RSB, Silva Sobrinho AG, Yamamoto SM, Barbosa JC. Tecidual composition of carcass of cuts of young and adult 
sheep. Pesq Agropec Bras 2007;42:565-71.

26. Frescura RBM, Pires CC, Silva JHS, et al. Evaluation of carcass cuttings proportion, meat characteristics and evaluation of live weight components of lambs. R Bras Zootec 2005;34:16774.

27. Silva Sobrinho AG, Azevedo Silva AM, Gonzaga Neto S. Feeding systems and in vivo and carcass traits of lambs in drylot. Agropec Cient Semi-Árido 2005;1:39-45.

28. Wood JD, Mcfie JHD, Pomeroy RW, Twinn DI. Carcass com- position in four shepp breeds: the importance of type of breed and stage of maturity. Anim Prod 1980;30:135-52.

29. Urbano AS, Ferreira MA, Véras RML, et al. Carcass characteristics and tissue composition of Santa Ines sheep fed manipueira. R Bras Ciênc Agrár 2015;10:466-72.

30. Monte ALS, Selaive-Villarroel AB, Pérez JRO, et al. Commercial CUT and tissue yields in carcasses from crossbred kid goats. R Bras Zootec 2007;36:2127-33. 